\title{
IMPLEMENTASI MANAJEMEN PENDIDIKAN ISLAM DALAM MEMBINA KEPRIBADIAN ISLAMI DI SMA ISLAM TERPADU MIFTAHUL KHOIR DAGO BANDUNG
}

\author{
Casiska Winda,* A. Syamsu Rizal, dan Toto S. Afriatin \\ Universitas Pendidikan Indonesia \\ *E-mail: casiska.winda94@student.upi.edu
}

\begin{abstract}
Various education policies have been developed to achieve the national education objective, including the policy of Islamic education management. The research aims to find about the management of education program policies, management of educators and education personnel, management of curriculum and lesson planning, instructional management, infrastructure management, financial management, and assessment system management, especially at Miftahul Khoir Integrated Islamic Senior High School. Using a qualitative-descriptive approach, data were collected through observation, interviews, and documentary studies. Based on the research results, the management of education at Miftabul Khoir Integrated Islamic Senior High School is integrated well, and appropriate to The Unity of Knowledge theory, including the policy, the personnel, the curriculum, facilities and structures, the financial, and also the assessment system.
\end{abstract}

Keywords:Islamic Education, Islamic Education Management, Islamic Personality.

\begin{abstract}
ABSTRAK
Berbagai macam kebijakan pendidikan telah dikembangkan untuk mencapai tujuan nasional tersebut, termasuk kebijakan manajemen pendidikan Islam. Penelitian ini bertujuan untuk mengetabui manajemen kebijakan program pendidikan, manajemen pendidik dan tenagakependidikan, manajemen kurikulum dan perencanaan pembelajaran, manajemen pembelajaran, manajemen sarana prasarana, manajemen pembiayaan, dan manajemen sistem penilaian, khususnya di SMA Islam Terpadu Miftahul Khoir. Dengan menggunakan pendekatan kualitatif-deskriptif, pengumpulan data dilakukan melalui observasi, wawancara, dan studi dokumentasi. Berdasarkan basil penelitian, manajemen pendidikan Islam SMA Islam Terpadu Miftabul Khoir bersifat terpadu sesuai dengan teori The Unity of Knowledge, yang meliputi kebijakan program pendidikannya, personel sekolabnya, kurikulumnya, sarana dan prasarana, keuangannya, dan juga sistem penilaiannya.
\end{abstract}

Kata Kunci:Kepribadian Islam, Manajemen Pendidikan Islam, Pendidikan Islam. 


\section{PENDAHULUAN}

Pendidikan menjadi hal yang tidak dapat terpisahkan dari kehidupan manusia. Manusia mulai sejak lahir sangat membutuhkan pendidikan untuk mengembangkan seluruh potensi yang dimilikinya. Pendidikan juga menjadi upaya memanusiakan manusia, karena manusia yang baru lahir ke dunia tidak berdaya, tidak dilengkapi insting yang sempurna. Dengan demikian, manusia sebagai makhluk harus dan perlu dididik dan mendidik, manusia juga sebagai makhluk yang bisa dididik dan mendidik (Waini Rasyidin; dkk, 2013).

Adapun tujuan nasional pendidikan adalah:

"Pendidikan adalah usaha sadar dan terencana untuk mewujudkan suasana belajar dan proses pembelajaran agar peserta didik secara aktif mengembangkan potensi dirinya untuk memiliki kekuatan spiritual keagamaan, pengendalian diri, kepribadian, kecerdasan, akhlak mulia, serta keterampilan yang diperlukan dirinya, masyarakat, bangsa dan negara" (Undang-Undang Sistem Pendidikan Nasional No. 20 Tahun 2003).

Berbagai perundangan dan peraturan yang dihasilkan oleh pemerintah seperti UU Nomor 20 tahun 2003 tentang Sistem Pendidikan Nasional di atas yang mengatur pendidikan Islam. Peraturan perundangan tersebut mau tidak mau memacu seluruh pelaku pendidikan Islam untuk membenahi seluruh aspek dalam pendidikan Islam agar bisa setara, bahkan lebih berkualitas dibandingkan dengan pendidikan umum yang lebih dahulu matang dan mapan (Setyaningsih, hlm. 34).

Untuk itu, guna mewujudkan pendidikan yang bermutu, yaitu pendidikan yang mampu mengembangkan kemampuan, membentuk karakter dan peradaban bangsa (Khori, Mei 2016, hlm. 76), perlu dikembangkan pendidikan dengan menerapkan nilai-nilai keIslaman.

Berkenaan dengan pendidikan dikemukakan Dr. Zakiah Daradjat dkk, (2016, hlm. 34) antara lain sebagai berikut:

"Pendidikan berlangsung seumur hidup dan dilaksanakan di dalam lingkungan rumah tangga, sekolah, dan masyarakat. Karena itu pendidikan adalah tanggung jawab bersama antara keluarga, masyarakat, dan pemerintah."

Pernyataan di atas menunjukkan bahwa pendidikan secara umum dilaksanakan melalui lembaga pendidikan formal, non-formal, dan informal. Di Indonesia sekolah menjadi lembaga pendidikan formal yang terdiri dari beberapa jenjang, dimulai dari jenjang Sekolah Dasar, Sekolah Menengah (Sekolah Menengah Pertama dan Sekolah Menengah Atas), dan Perguruan Tinggi. Dengan adanya pendidikan di sekolah-sekolah diharapkan mampu menciptakan hasil belajar yang optimal, guna mencapai tujuan pendidikan. Tidak heran jika sistem pendidikan di Indonesia banyak mengambil kebijakan melalui penetapan kurikulum. Kebijakan pemerintah dalam menetapkan kurikulum sejatinya

TARBAWY: Indonesian Journal of Islamic Education - Vol. 4 No. 2 (2017) | 163 
sebagai upaya mewujudkan tujuan pendidikan. Dalam sejarah tercatat sejak tahun 1945, kurikulum pendidikan nasional telah mengalami perubahan, dimulai dari 1) Kurikulum Rencana Pelajaran (1947-1968), 2) Kurikulum Berorientasi Pencapaian Tujuan (1975-1994), 3) Kurikulum Berbasis Kompetensi dan KTSP (2004/ 2006), dan 4) Kurikulum 2013 (Fitriya, 2014).

Semua kurikulum yang ditetapkan bertujuan sama, yakni supaya bisa mencapai tujuan pendidikan nasional. Namun, hingga saat ini melalui penetapan Kurikulum 2013, yang idealnya dapat menjadikan siswa menjadi masyarakat yang peduli, toleran, dan memiliki intelektual tinggi, ternyata di lapangan masih banyak ditemukan berbagai permasalahan. Permasalahan mencolok yang belakangan ini terjadi di dunia pendidikan antara lain rendahnya moralitas siswa. Masalah moralitas siswa dan remaja dewasa ini menurut Syahidin (2009, hlm. 3) sudah menjadi problema umum yang belum ditemukan solusinya. Di Indonesia, kenakalan remaja saat ini sudah sangat memprihatinkan. Bahkan di lingkungan pendidikan yang statusnya sebagai pelajar tindakannya sudah mulai menyimpang dari peraturan, mulai dari meniru gaya gaul yang belum tentu benar, keras kepala, tidak patuh terhadap orang tua dan guru, membolos sekolah, tidak mau belajar, suka berkelahi, kurang sopan, cara berpakaian yang tidak benar, merokok, minum-minuman keras, pornografi, bahkan sudah sampai terlibat narkoba, seks bebas dan hamil di luar
nikah(Mahmudin, 2012). Padahal pelajar adalah bagian dari masyarakat, bangsa dan negara yang merupakan sumber potensial dari suatu negara, mereka turut bertanggung jawab atas berhasil tidaknya pembangunan yang sedang berlangsung.

Padahal jika mengacu pada tujuan pendidikan seharusnya pendidikan dapat menghasilkan kepribadian yang baik. Sesuai dengan keadaan dewasa ini, sekolah sebagai tempat pendidikan dan dapat pula menjadi sumber konflik di antara remaja. Penegakan disiplin, ketertiban, kesopanan, kesusilaan, pengawasan diperketat dengan lebih bersifat edukatif dan persuasif. Kesamaan pandang dan langkah antara guru dan segenap civitas akademika mempengaruhi keberhasilan pembinaan moral siswa di sekolah dengan tidak mengesampingkan peran orang tua. Keaktifan guru yang mengajar adalah juga merupakan salah satu faktor yang bisa mengatasi kenakalan remaja(Mahmudin, 2012). Maka di sinisekolah tidak hanya menambahkan jam pelajaran PAI yang lebih lama, tapi dari segi materi, metode, dan guru yang mengajar harus berpegang kepada prinsip pendidikan Islam. Maka jadilah pendidikan Islami, yaitu pendidikan yang berdasar Islam, artinya pendidikan berlangsung sesuai dengan ajaran Islam (Tafsir, 2013, hlm. 310).

Sedangkan Karim menyebutkan pendidikan Islam adalah proses mempersiapkan generasi muda (pembentukan individu) untuk menjalankan kehidupan (sebagai khalifah) dan untuk memenuhi tujuan 
hidup secara efektif dan efisien berdasarkan sumber-sumber Islam berupa Alqur'an, Hadis, dan Ijtihad.

Mengenai kata khilafah, Allahberfirman dalam Alqur'an Surat Fathir/35: 39 berikut,
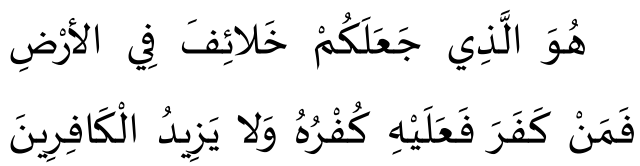

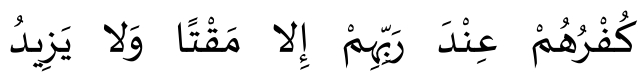

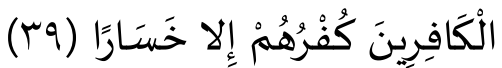

Artinya: "Dialah yang menjadikan kamu sebagai khalifah-khalifah di bumi. Barangsiapa kafir, maka (akibat) kekafirannya akan menimpa dirinya sendiri. Dan kekafiran orang-orang kafir itu hanya akan menambah kemurkaan di sisi Tuban mereka. Dan akan menambah kerugian mereka belaka (35)"'(QS. Fathir/35: 39).

Muhaimin (2012, hlm. 22) menjelaskan, kata khalifah berasal dari kata khalf (menggantikan, mengganti) atau kata khalaf (orang yang datang kemudian) sebagai lawan dari kata salaf (orang yang terdahulu). Tugas manusia sebagai khalifah Allah di muka bumi antara lain menyangkut tugas mewujudkan kemakmuran di muka bumi dan mewujudkan keselamatan dan kebahagiaan hidup di muka bumi, yaitu dengan cara beriman dan beramal sholeh juga bekerja sama dalam menegakkan kebenaran dan dalam menegakkan kesabaran. Yang mana tugas-tugas kekhalifahan tersebut dikembangkan dalam bentuk tugas kekhalifahan terhadap diri sendiri (termasuk menuntut ilmu pengetahuan), tugas kekhalifahan dalam keluarga, tugas kekhalifahan di masyarakat, dan tugas kekhalifahan terhadap alam.

Untukmerealisasikankonseppe ndidikan Islam telah dilakukan upaya sejak awal abad ke-20 baik oleh perorangan, lembaga, atau organisasi (Sirozi \& dkk, 2008, hlm. 315). Sekolah Menengah Atas Islam Terpadu Miftahul Khoir juga menjadi salah satu bukti upaya perjuangan tersebut. Kini sekolah yang sudah berdiri sejak tahun 2002 ini merupakan sekolah yang mengintegrasikan pendidikan modern denganpendidikan agama, di mana yang menjadi keunggulan dari SMA Islam Terpadu Miftahul Khoir yakni dalam setiap kegiatan tidaklepas dari aspek keagamaan. Salah satu bentuknya dapat dilihat dari adanya pembiasaan membaca al-ma'surat sebelum dan sesudah KBM dilaksanakan, yakni pada pagi hari saat masuk kelasdan pada sore hari saat pulang. SMA Islam Terpadu Miftahul Khoir merupakan sekolah full day school di mana pembelajaran berlangsung sejak pukul 07.00-15.40 WIB, sehingga dengan durasi waktu tersebut seluruh peserta didik senantias amelakukan sholat dzuhur dan ashar secara berjama'ah.

Warna pendidikan yang cukup unik tersebut membuat penulis tertarik meneliti lebih jauh tentang rangkaian proses pendidikan di SMA Islam Terpadu Miftahul Khoir secara lebih mendalam. Terlebih dengan kondisi moral pelajar saat ini, dengan system pendidikan yang dimiliki SMA Islam Terpadu Miftahul Khoir akan sangat membantu meminimalisir krisis moral

TARBAWY: Indonesian Journal of Islamic Education - Vol. 4 No. 2 (2017) $\mid \mathbf{1 6 5}$ 
pelajar saat ini. Untuk itu, penulis tertarik untuk melakukan penelitian dengan judul "Implementasi Manajemen Pendidikan Islam dalam Membina Kepribadian Islami di SMA Islam Terpadu Miftahul Khoir Dago Bandung".

\section{METODE PENELITIAN}

Metode penelitian dalam penelitian ini menggunakan pendekatan kualitatif dengan metode deskriptif. Penelitian deskriptif menurut Achmadi (2009, hlm. 44) merupakan penelitian yang berusaha untuk menuturkan pemecahan masalah yang ada sekarang berdasarkan data-data, jadi ia juga menyajikan data, menganalisis dan menginterpretasi. Tujuan penelitian ini yaitu untuk pemecahan masalah secara sistematis dan faktual mengenai faktafakta dan sifat-sifat populasi.

Dalam penelitian ini peneliti menggunakan tahapan-tahapan penelitian, sebagaimana menurut Moleong (2014, hlm. 127), ada tiga tahapan dalam penelitian: tahap pra penelitian, tahap pelaksanaan penelitian, dan tahap analisis data.

Adapun teknik pengumpulan data implementasi manajemen pendidikan Islam di SMA Miftahul Khoir Dago Bandung yang digunakan dalam penelitian ini menggunakan teknik observasi, wawancara, studi dokumentasi dan triangulasi. Analisis data adalah proses mengatur urutan data, mengorganisasikannya ke dalam suatu pola, kategori, dan satuan uraian dasar (Moleong, 2014, hlm. 280). Ada tiga tahapan dalam menganalisis data yang digunakan dalam penelitian ini, yaitu reduksi data (data reduction), penyajian data (display data), dan penarikan kesimpulan (conclution drawing/verifying).

\section{HASIL PENELITIAN DAN PEMBAHASAN}

1. Kebijakan

Program

Pendidikan Islam

SMA Islam Terpadu Miftahul Khoir memiliki beberapa program dalam menunjang keberhasilan pendidikan Islam, di antaranya adalah Pesantren Sains, Nature Research, Saba Bandung, Panggung Ekspresi, Halaqah, Qur'an Camp, Be Your Self, Sahabat Desa, Sarasehan, H2S (Hari-Hari Sains), Motivasi and Training (Morning), dan Sidang Karya Ilmiah.

Pesantren

Sains

(Sansai) merupakan program pembelajaran terpadu meliputi bidang studi agama, ekonomi-kewirausahaan, bahasa, sejarah, sosiologi, dan kepemimpinan; dilaksanakan setiap Ramadhan. Nature Research (NR) merupakan program pembelajaran terpadu meliputi bidang studi Matematika, Fisika, Kimia, Biologi, Agama, dan Kepemimpinan; dilaksanakan setiap semester genap. Saba Bandung merupakan program mengunjungi pusat-pusat belajar yang ada di Kota Bandung dan sekitarnya untuk memperkaya dan memperdalam pengetahuan. Panggung Ekspresi merupakan kegiatan pementasan seni, seperti kisah para sahabat nabi atau pementasan puisi. Halaqab atau mentoring agama merupakan program pengembangan pendidikan Islam secara tematik dalam kelompok kecil. 
Qur'an Camp merupakan kegiatan camping yang kegiatannya banyak interaksi dengan Alqur'an. Be Your Self merupakan program khusus para siswa kelas XI yang berisi pelatihan motivasi, kepemimpinan, dan kepribadian melalui studi fenomena kehidupan, kerja sama tim, simulasi, permainan, dan tadabbur akhirat. Sahabat Desa ini adalah program yang dilakukan pada saat hari qurban, kegiatannya yaitu menyalurkan hewan qurban ke daerah yang tidak ada qurban. Sarasehanmerupakan program perbincangan siswa dengan narasumber dari berbagai kalangan dan profesi, seperti peneliti, pengusaha, pelaku media massa, pemerhati lingkungan, dokter, LSM, dan sebagainya. H2S (Hari-Hari Sains), merupakan kegiatan di saat para siswa menampilkan karya-karya terapan IPTEK hasil percobaan mereka. Motivation and Training erupakan program pelatihan motivasi bagi para siswa kelas XII untuk persiapan menghadapi ujian Nasional dan SBMPTN.

Dari keseluruhan program tersebut menunjukkan pendidikan yang komprehensif. Pendidikan memang seharusnya bertujuan mencapai pertumbuhan yang seimbang dalam kepribadian manusia secara total melalui pelatihan spiritual, kecerdasan, rasio, perasaan, dan panca-indera. Oleh karena itu, pendidikan seharusnya pelayanan bagi pertumbuhan manusia dalam segala aspeknya yang meliputi aspek spiritual, intelektual, imajinasi, fisik, ilmiah, linguistik, baik secara individu maupun secara kolektif dan memotivasi semua aspek tersebut ke arah kebaikan dan pencapaian kesempurnaan. Tujuan utama pendidikan bertumpu pada terealisasinya ketundukan kepada Allah Swt., baik dalam level individu, komunitas, dan manusia secara luas (Abdul Mujib; et.al, 2008, hlm. 83).

\section{Pendidik dan Tenaga Kependidikan SMA Islam Terpadu Miftahul Khoir \\ Dalam pengelolaan tenaga} pendidik dan tenaga kependidikan di SMA Islam Terpadu Miftahul Khoir dari segi kualifikasi akademik mayoritas pendidik sudah bergelar sarjana. Pendidik di SMA Islam Terpadu Miftahul Khoir kualifikasinya beragam, ada yang lulusan UNPAD, ITB, pesantren, UPI, mayoritasnya dari UPI. Adapun untuk pendidik yang sertifikasi ada 4 orang, diantaranya adalah Guru B. Indonesia, Guru PKN/Kepemimpinan, Guru Ekonomi, dan Guru Fisika. Adapun untuk tenaga kependidikan ada tiga jenis, yaitu sarjana, diploma, dan lulusan SMA.

Baik pendidik maupun tenaga kependidikan di SMA Islam Terpadu Miftahul Khoir, dikelola supaya satu tujuan. Tujuannya yaitu bahwa manusia diciptakan tujuannya adalah menjadi manusia yang bertakwa, sehingga dalam pembelajaran di kelas dibebaskan dalam hal administrasi dan mengemas pembelajaran sekreatif mungkin. Sebagaimana Kosim (Tadris Vol. 3 Nomor I, 2008, hlm. 45) menyebutkan bahwasannya dalam Islam, sosok guru sangat strategis, di samping mengemban misi keilmuan agar peserta didik menguasai ilmu-ilmu 
agama, guru juga mengemban tugas suci, misi kenabian, yakni membimbing dan mengarahkan peserta didik menuju jalan Allah Swt. Untuk itulah mereka Mereka membekali diri dengan mengkaji Kitab Ta'lim Muta'allim yang kemudian dijadikan sebagai acuan mereka dalam memberikan pengajaran di kelas.

Sertifikasi tidak dijadikan tolak ukur dalam keprofesionalan dan kompetensi dalam mengajar, SMA Islam Terpadu Miftahul Khoir memiliki program dan persyaratan tersendiri bagi seorang pendidik. Selain mengajar dengan menjadikan prinsip "menjadi manusia yang bertakwa" sebagai acuan mereka juga dibebaskan dalam segi administrasi pembelajaran, seperti dalam pembuatan RPP dan administrasi lainnya. Seperti dikemukakan pada poin temuan di atas, bahwa persyaratan menjadi seorang pendidik di antaranya: 1) beragama Islam, 2) bisa mengaji, 3) pendidikan minimal sarjana dan sesuai bidang, 4) dapat berimprovisasi dengan baik ketika mengajar, 5) tidak merokok, 6) diutamakan yang juga seorang hafizh/hafizhah, 7) menyukai travelling, dan 8) siap dengan honor yang kecil.

Pendidikan Islam juga sangat menekankan pendidik yang profesional, yaitu pendidik yang selain memiliki kompetensi akademik, paedagogi dan sosial, juga kompetensi kepribadian. Dengan kompetensi akademik mutu penguasaan ilmu pengetahuan dan keterampilan akan dapat dicapai. Dengan kompetensi paedagogi proses belajar mengajar akan dapat dilaksanakan secara efisien dan efektif. Dengan kompetensi sosial, keterlibatan masyarakat, stakeholder, dan lainnya dalam menunjang keberlangsungan pendidikan akan dapat diberdayakan dan dimaksimalkan. Kemudian dengan kompetensi kepribadian, hasil pendidikan dan pengajaran akan dapat mempengaruhi pembentukan watak dan karakter peserta didik yang baik (Nata, 2010, hlm. 171).

\section{Kurikulum dan Rencana Pembelajaran Pendidikan Islam}

Kurikulum yang digunakan di SMA Islam Terpadu Miftahul Khoir adalah Kurikulum 2013 yang dalam pengembangannya sekolah memadukannya dengan Kurikulum Dinul Islam dan Kurikulum Lokal. Program jurusan yang dikembangkan hanya program IPA.

Konsep Kurikulum Terpadu tidak hanya sekedar memberi tambahan materi atau muatan dari kurikulum diknas, tetapi muatan tambahan tersebut diaplikasikan dan dikembangkan dalam berbagai program pembelajaran (ko kurikuler dan ekstra kurikuler), pembiasaan nilai-nilai ajaran Islam, dan proses penilaian. Contoh keterpaduan dalam program pembelajaran (ko kurikuler)

Salah satu bentuk keterpaduannya melalui pembelajaran di kelas maupun di luar kelas, di mana pendidik mengaitkan fenomena yang dialami atau dipelajari dengan nilainilai Islam atau nilai Tauhid dalam rangka mengenalkan peserta didik kepada Allah Swt. 
Konsep keterpaduan yang dimaksud dalam ilmu pengetahuan sebenarnya sudah diaplikasikan di sekolah ini. Baik melalui beberapa kebijakan program pendidikan maupun melalui mata pelajaran-mata pelajaran itu sendiri. Apabila ditinjau dari teori keterpaduan atau dalam konsep kesatuan ilmu pengetahuan (the unity of knowledge) menurut Ahmad Syafii Maarif yang dikutip dari Skripsi yang ditulis Afrinaldi (2012, hlm. 15) ilmu pengetahuan dikategorikan kepada tiga tipe, yaitu: Pertama, ilmuilmu kealaman atau ilmu-ilmu fisikal, yang dapat dikuasai manusia. Kedua, ilmu sejarah dan geografi yang sangat penting bagi kemajuan peradaban manusia. Dan yang ketiga, ilmu pengetahuan tentang diri manusia sendiri, di samping ilmu tentang alam. Dari teori kesatuan ilmu pengetahuan tersebut jelaslah bahwa semua mata pelajaran yang dipelajari sangat berkaitan erat dengan Islam.

\section{Pembelajaran Pendidikan} Islam

Kegiatan belajar mengajar berlangsung selama 5 hari, yaitu dari hari Senin-Jumat. Adapun hari Sabtu digunakan untuk kegiatan ekstrakurikuler. Kegiatan belajar mengajar setiap harinya dimulai pukul 07.00-15-40 WIB, kecuali hari Jumat dari pukul 07.00-14.40 WIB. Yang menjadikan sekolah ini berbeda dengan sekolah lain, karena merupakan sekolah Islam Terpadu, maka diawali dengan kegiatan Pembiasaan Pagi yang terdiri dari membaca al-ma'surat pagi dan shalat dhuha. Kegiatan Pembiasaan Pagi setiap harinya berlangsung selama 15 menit, yaitu dari pukul 07.00-07.15 WIB. Pembacaan al-ma'surat dibimbing oleh salah seorang pendidik yang piket, kemudian dipimpin oleh salah seorang peserta didik. Pembiasaan Pagi ini dilakukan di Masjid Yayasan Miftahul Khoir. Selain dari kegiatan Pembiasaan Pagi, yang menjadi ciri khas dari sekolah ini adalah Mata Pelajaran Tahsin dan Tahfizh yang juga dilaksanakan setiap pagi setelah Pembiasaan Pagi selesai. Tahsin dan Tahfizh merupakan mata pelajaran yang waktunya dialokasikan 4 hari dalam seminggu, yaitu dari hari Senin-Kamis dimulai pukul 07.1508.15 WIB. Baik Pembiasaan Pagi maupun Mata Pelajaran Tahsin dan Tahfizh diikuti serentak oleh seluruh peserta didik kelas X-XII yang keduanya dilakukan di masjid. Setelah kegiatan tersebut selesai, mereka memasuki kelas masing-masing dan melakukan KBM sesuai jadwal pelajaran kelas masing-masing.

Kegiatan Pembiasaan Pagi dan Pembiasaan Sore yang berisi dzikir tersebut sesuai dengan anjuran berdzikir sudah Allah sebutkan dalam QS. Al-Ahzab/33: 41-42 yang artinya:

"Hai orang-orang yang beriman, berzdikirlah (dengan menyebut nama) Allah, zikir yang sebanyak-banyaknya (41) dan bertasbiblah kepada-Nya diwaktu pagi dan petang (42)"

Dari firman Allah tersebut di atas merupakan anjuran agar berdzikir di waktu pagi dan petang. Hal ini sebagaimana telah diimplementasikan di SMA Islam Terpadu Miftahul Khoir, yakni dengan dilaksanakannya 
Pembiasaan Pagi dan Pembiasaan Sore, sebelum dan sesudah pembelajaran berlangsung membaca doa al-ma'surat pagi dan petang. Kemudian dilanjut dengan Mata Pelajaran Tahsin dan Tahfizh setiap harinya, dari SeninKamis sehingga peserta didik lebih banyak berinteraksi dengan Alqur'an dan pengamalannya secara langsung pada saat belajar di kelas dengan mata pelajaran-mata pelajaran lain tentang keilmuan alam, sejarah, dan kemanusiaan.

\section{Sarana dan Prasarana Pendidikan Islam}

Sarana Prasarana yang menunjang pendidikan Islam yang disediakan di SMA Islam Terpadu Miftahul Khoir di antaranya terdiri dari Alqur'an, alat sholat, masjid, toilet ikhwan, toilet akhwat, UKS, Ruang Guru, Ruang Kepala Sekolah, Ruang TU, Perpustakaan, laboratorium, Ruang Kelas, Ruang BK, lapangan olahraga, area parkir, audio, proyektor, dan tempat sampah.

Sebagaimana

Peraturan

Pemerintah No. 19 Tahun 2005 tetang Standar Nasional Pendidikan yang menyangkut standar sarana dan prasarana pendidikan secara nasional pada Bab VII Pasal 42 dengan tegas disebutkan bahwa:

"Pertama, setiap satuan pendidikan wajib memiliki sarana yang meliputi perabot, peralatan pendidikan, media pendidikan, buku dan sumber belajar lainnya, bahan habis pakai, serta perlengkapan lain yang diperlukan untuk menunjang proses pembelajaran yang teratur dan berkelanjutan. Kedua, setiap satuan pendidikan wajib memiliki prasarana yang meliputi lahan, ruang kelas, ruang pimpinan satuan pendidikan, ruang pendidik, ruang tata usaha, ruang perpustakaan, ruang laboratorium, ruang bengkel kerja, ruang unit produksi, ruang kantin, instalasi daya dan jasa, tempat berolah raga, tempat beribadah, tempat bermain, tempat bekreasi, dan ruang/tempat lain yang diperlukan untuk menunjang proses pembelajaran yang teratur dan berkelanjutan" (dalam Darmawan 2014, hlm. 94).

Sarana prasarana yang disediakan digunakan dengan baik, beberapa digunakan juga untuk proses pembelajaran. Sedikitnya jumlah peserta didik memungkinkan untuk melangsungkan pembelajaran, seperti masjid, Ruang TU, perpustakaan, laboratorium atau bahkan di lingkungan sekitar sekolah.

\section{Pembiayaan Pendidikan Islam \\ Pembiayaan pendidikan Islam di} SMA Islam Terpadu Miftahul Khoir menunjukkan bahwa ada 3 sumber dana pendidikan: dana dari orang tua peserta didik, dana dari masyarakat, dan dana dari pemerintah.

Dana dari orang tua peserta didik meliputi SPP sebesar Rp. 500.000,-, Dana Awal Pendidikan (DAP) atau disebut uang pangkal Rp. 11.000.000,-, dan ada Dana Kegiatan sebesar Rp. 1.500.000,-. Adapun dana dari masyarakat yaitu dana bantuan dari masyarakat, sifatnya bantuan, jadi tidak mengikat. Sedangkan dana dari 
pemerintah,yakni dari pemerintah pusat, provinsi, dan kota.

Biaya pendidikan merupakan salah satu komponen masukan instrumental (instrumental input) yang sangat penting dalam penyelenggaraan pendidikan (di sekolah). Biaya dalam pengertian ini memiliki cakupan sangat luas, yakni semua jenis pengeluaran yang berkenaan dengan penyelenggaraan pendidikan, baik dalam bentuk uang maupun barang dan tenaga (yang dihargakan dengan uang). Dalam pengertian ini, misalnya iuran siswa adalah jelas merupakan biaya, tetapi sarana fisik, buku sekolah dan guru juga adalah biaya. Bagaimana biaya-biaya itu direncanakan, diperoleh, dialokasikan, dan dikelola merupakan persoalan pembiayaan atau pendanaan pendidikan (educational finance) (Supriadi, 2006, hlm. 3).

Sumber-sumber pembiayaan pendidikan secara makro telah diatur dalam pasal 31 UUD 1945 yang mengamanatkan pemerintah pusat dan daerah bertanggung jawab menyediakan anggaran pendidikan. Dipertegas lagi oleh Undang-Undang Sistem Pendidikan Nasional JUSPN Tahun 2003 pasal 49 ayat (2) yang menyatakan bahwa: "Dana pendidikan selain gaji pendidik dan biaya pendidikan kedinasan dialokasikan minimal 20\% dari Anggaran Pendapatan dan Belanja Negara (APBN) pada sektor pendidikan dan minimal 20\% dari Anggaran Pendapatan dan Belanja Daerah (APBD)". Pembiayaan pendidikan dengan asumsi bahwa pembiayaan pendidikan tidak boleh lepas dari kebijaksanaan keuangan negara. Juga asumsi yang lain ialah bahwa kegiatankegiatan pendidikan itu adalah dalam rangka pencapai tujuan pembangunan nasional (Arifi, 2008, hlm. 114).

Keseluruhan dana pendidikan Islam tersebut setiap bulannya dialokasikan yang terbesar untuk honor, kedua itu untuk kegiatan, ketiga itu rumah tangga seperti listrik, telpon, koran, termasuk di dalamnya ATK. Yang keempatnya baru untuk belanja barang (sarana), itu biasanya dinomorempatkan karena melihat dulu kemungkinannya atau perkiraan tahun ajaran selanjutnya ada berapa siswa. Honor atau gaji guru menjadi prioritas yang paling besar karena meskipun jumlah siswanya sedikit tapi di sekolah ini memang mengupayakan yang terbaik untuk seorang pendidik. Sebagaimana kita ketahui bahwa tugas seorang guru bukanlah tugas yang mudah dan bukan pula tugas yang bisa dilakukan semua orang. Karena itulah tugas seorang guru merupakan tugas yang mulia dan istimewa. Selain itu di SMA Islam Terpadu Miftahul Khoir ini juga seorang guru dituntut dapat mendidik anak bangsa menjadi insan yang bertauhid, dan bisa mencapai keridhaan Allah. Untuk itu, seorang guru harus memiliki komitmen yang kuat dan tentunya rela berkorban. Maka sudah sepantasnyalah mereka dibahagiakan dengan prioritas honor dari sekolah.

\section{Evaluasi Pendidikan Islam \\ Di SMA Islam Terpadu Miftahul} Khoir ada 3 bentuk evaluasi yang biasa digunakan di SMA Islam Terpadu Miftahul Khoir, yaitu dalam bentuk

TARBAWY: Indonesian Journal of Islamic Education - Vol. 4 No. 2 (2017) | 171 
tulis, verbal, dan project. Namun, ada juga jenis evaluasi praktek yang lebih dominan, karena setiap harinya selalu ada evaluasi praktek dari sebelum KBM sampai sesudah KBM berlangsung.

Dengan sistem evaluasi seperti ini akan menunjang keberhasilan pendidikan, karena sebagai alat penilaian hasil pencapaian tujuan dalam pengajaran, evaluasi harus dilakukan secara terus menerus. Evaluasi tidak hanya sekadar menentukan angka keberhasilan belajar, tetapi menurut Djamarah (2005, hlm. 245) dengan mengutip pendapat Ali bahwa yang lebih penting adalah sebagai dasar untuk umpan balik dari proses interaksi edukatif yang dilaksanakan.

Menurut Nata (2010, hlm. 312) evaluasi juga dilaksanakan dengan prinsip bahwa apa yang dievaluasikan merupakan bagian integral dari proses belajar mengajar, bersifat komparabel; yakni dapat dibandingkan antara satu tahap penilaian dengan tahap penilaian lainnya, serta memiliki kejelasan bagi para siswa, dan bagi para pengajar itu sendiri. Dalam hal ini, evaluasi praktek yang dominan dilaksanakan di SMA Islam Terpadu Miftahul Khoir sangat berkaitan erat dan merupakan bagian integral dari proses belajar. Selain itu, berbagai jenis kebijakan program seperti Nature Research, Pesantren Sains, dan sebagainya juga dimasukan sebagai bagian integral dari evaluasi pembelajaran terkait dengan beberapa mata pelajaran yang menunjang. Terlebih tujuan utama pembelajaran di SMA Islam Terpadu Miftahul Khoir adalah menjadikan peserta didik menjadi insān kamìl yang bertauhid. Maka dengan dominasi praktek yang menjadi sebuah kebiasaan ini akan membentuk kepribadian atau mempribadi. Mempribadi di sini sebagaimana menurut Rizal dalam Jurnal Pendidikan Agama Islam (2010, hlm. 23) yaitu:

"suatu tipe kepribadian yang terbentuk dari pengaruh-pengaruh ajaran Islam yang merasuk ke dalam diri seseorang sehingga mempribadi. Ia adalah suatu kepribadian yang terbentuk dari nilai-nilai keislaman, yang bersumber dari Alqur'an dan Assunnah, yang dengan nilai-nilai Islam tersebut individu membangun pola pikir, pola sikap, dan pola perilakunya sehingga menjadi karakter yang membedakan dirinya dari diri-diri yang lainnya."

Evaluasi praktek ini merupakan aplikasi langsung dari ajaran utama, yakni Alqur'an dan Hadis yang dikemas ke dalam kurikulum/mata pelajaran SMA Islam Terpadu Miftahul Khoir. Sekolah yang lebih mengedepankan mengambil nilai-nilai Islam dari kehidupan nyata secara langsung, memberikan gambaran yang jelas terhadap peserta didik sehingga mudah dipahami. Pendidikan yang berhasil menurut perspektif SMA Islam Terpadu Miftahul Khoir adalah pendidikan yang bisa menghasilkan perubahan, bukan berarti dengan nilai akademik yang tinggi saja, melainkan lebih menekankan pada kebiasaan sehari-hari yang dilakukan oleh peserta didik, baik itu dalam praktek ibadah sholat maupun dalam mata pelajaran lainnya. Hal ini sesuai dengan pernyataan Tafsir dalam Seminar 
Nasional dan Pelatihan Guru PAI (Kamis, 4 Mei 2017) yang mengatakan bahwa:

"Pendidikan Islami itu fokusnya jangan scientik, tapi akhlak. Pendidikan agama sebetulnya pendidikan kepribadian. Jangan gunakan teori pengajaran dari Barat. Taksonomi Bloom digunakan untuk PAI itu salah. Seharusnya Taksonomi Bloom itu untuk Seni dan Estetika. Kita terapkan saja Learning to Know, Learning to Do, Learning to Be. Nabi Muhammad Saw. bisa mengubah akhlak dalam 23 tahun, metodenya yang pertama 1) sedikit pengajaran, 2) banyak peneladanan, 3) banyak pembiasaan, 4) pemotivasian, 5) penegakkan aturan, dan ada satu metode tambahan yaitu 6) menyediakan lapangan pekerjaan. Peneladanan dalam istilah sekarang disebut dengan role model. Jangan sampai tidak ada biaya kemudian tidak ada proyek, bukan pemikiran pendidikan.”

\section{KESIMPULAN}

Berdasarkan hasil temuan dan pembahasan mengenai implementasi manajemen pendidikan Islam dalam membina kepribadian Islami di SMA Islam Terpadu Miftahul Khoir dapat disimpulkan bahwa kebijakan program pendidikan Islam dalam membina kepribadian Islami di SMA Islam Terpadu Miftahul Khoir sangat bagus, karena dari keseluruhan program yang terdiri dari Pesantren Sains, Nature Research, Saba Bandung, Panggung Ekspresi, Halaqah, Qur'an Camp, Be Your Self, Sahabat Desa, Sarasehan,
H2S (Hari-Hari Sains), Motivasi and Training (Morning), dan Sidang Karya Ilmiah yang dikemas dan dilaksanakan dengan tujuan mengembangkan potensi diri peserta didik dengan senantiasa memadukan aspek-aspek jasmani, rohani, dan akal pikiran dalam setiap pelaksanaan kegiatannya sesuai dengan Alqur'an dan Sunah. Sehingga peserta didik bisa menjadi insān kamìl yang siap mengemban tugas sebagai khalifah fil ardh.

Selain itu, dalam pengelolaan pendidik di SMA Islam Terpadu Miftahul Khoir disesuaikan/dengan keinginan peserta didik dan berkepribadian Islami sesuai yang ditetapkan sekolah. Meskipun dari segi kualifikasi akademik beberapa tenaga pendidiknya ada yang kurang sesuai bidang, seperti guru Mata Pelajaran PKN/Kepemimpinan, guru Mata Pelajaran Matematika khususnya Pak Gerry, dan guru Mata Pelajaran Biologi. Begitu juga kualifikasi tenaga kependidikannya, yakni dari jumlah 3 orang hanya ada satu yang memenuhi standar. Selain itu, tenaga pendidik yang sertifikasi baru berjumlah 4 orang, yaitu guru B. Indonesia, guru PKN/Kepemimpinan, guru Ekonomi, dan guru Fisika. Sertifikasi tidak menjadi persoalan penting, karena sebagian besar tenaga pendidik mengembangkan potensi diri mereka melalui kajian Kitab Ta'lim Muta'allim, yang mana mereka mengembangkan dan menggunakan prinsip pengajaran sesuai yang mereka pahami dari Kitab Ta'lim Muta'allim, sehingga sekolah membaskan sistem administrasi, contohnya RPP. Pendidik dituntut 
mengemas pembelajaran sekreatif mungkin sehingga bisa memasuki dunia peserta didik dan dapat diterima, untuk itu pendidik menjadikan kasih sayang sebagai prinsip mereka dalam memberikan pengajaran. Dalam hal perekrutan sendiri, SMA Islam Terpadu Miftahul Khoir membuka lowongan secara terbuka, yang mana persyaratannya digolongkan ke dalam persyaratan umum dan persyaratan khusus, yaitu yang pertama tentu harus beragama Islam, kedua bisa mengaji juga diutamakan memiliki hafalan Alqur'an, ini dalam rangka menjadikan mereka sebagai teladan langsung bagi peserta didiknya yang dituntut hafal Alqur'an di Mata Pelajaran Tahsin dan Tahfizh, kemudian yang ketiga harus berpendidikan minimal sarjana dan sesuai dengan bidang, yang keempat harus bisa berimprovisasi dengan baik dalam mengajar, kelima tidak merokok, keenam harus menyukai travelling karena di SMA Islam Terpadu Miftahul Khoir banyak agenda ke luar lingkungan sekolah, dan yang terakhir harus siap menerima honor yang kecil, karena menjadi seorang pendidik adalah tugas yang suci lagi mulia, untuk itu harus dilandasi dengan rasa tulus dan diniatkan karena Allah.

Kemudian dalam manajemen kurikulum dan perencanaan pembelajaran pendidikan Islam dalam membina kepribadian Islami di SMA Islam Terpadu Miftahul Khoir bersifat terpadu. Yang mana kurikulum tersebut muatannya terdiri dari muatan kurikulum diknas, muatan agama, dan muatan lokal yang dikembangkan sesuai dengan keadaan geografis dan kebutuhan SMA Islam Terpadu
Miftahul Khoir. Meski program yang dikembangkannya hanya IPA, SMA Islam Terpadu Miftahul Khoir menerapkan kurikulum diknas yang saat ini ditetapkan, yakni Kurikulum 2013 yang dipadukan dengan muatan Agama Islam dan muatan lokal. Perpaduan kurikulum tersebut melahirkan beberapa program pengembangan, seperti Nature Research dan Pesantren Sains sebagai pengembangan dari kurikulum diknas, kemudian program Tahsin/Tahfizh, Halaqah, Qur'an Camp, Qiyamul Lail dijadikan sebagai pengembangan muatan agama yang bertujuan untuk membekali dasar-dasar dinul Islam dan kekokohan keyakinan terhadap Dinul Islam kepada peserta didik, dan program Kepemimpinan dan Kewirausahaan sebagai pengembangan dari muatan lokal yang bertujuan untuk memberikan bekalan dasardasar kepemimpinan dan kewirausahaan kepada siswa agar kelak dapat hidup mandiri dan memberi manfaat bagi yang lain, tumbuh jiwa kepemimpinan dan kewirausahaan. Seluruh mata pelajaran yang terdapat di sekolah ini senantiasa dikaitkan dengan nilai-nilai ke-Islaman baik secara teori maupun pengalaman secara langsung di lapangan, pembelajaran senantiasa diarahkan pada unsur taubid.

Pembelajaran pendidikan Islam di SMA Islam Terpadu Miftahul Khoir menerapkan sistem full day school yang bersifat terpadu. Sistem pembelajaran senantiasa diawali dengan pembacaan al-ma'surat yang kemudian dilanjutkan dengan Mata Pelajaran Tahsin dan Tahfizh yang dilaksanakan di masjid 
secara serentak, antara kelas X, XI dan XII. Pembiasaan ini dilakukan untuk membiasakan peserta didik senantiasa berinteraksi dengan Alqur'an. Selain itu, masing-masing mata pelajaran dan masing-masing guru memiliki andil dalam pendidikan Islam. Hal ini karena di setiap mata pelajaran guru senantiasa mengaitkan materi dengan kehidupan nyata dan kejadian faktual yang dialami yang kemudian disandarkan kepada ayat-ayat Allah. Pembiasaan membaca al-ma'surat juga dilaksanakan setelah pembelajaran selesai, yakni setelah sholat Ashar berjama'ah. Di sekolah ini praktek sholat berjama'ah sudah menjadi pembiasaan sehari-hari, dimulai dari sholat Dhuha, Dzuhur, dan Ashar. Pembiasaan ini pun dijadikan sebagai penilaian kepada peserta didik sebagai upaya dari keberhasilan pendidikan Islam itu sendiri. Yang menarik adalah kebebasan pihak sekolah terhadap guru dalam memberikan pengajaran di kelas, pembelajaran tidak harus terpaku dengan RPP melainkan guru lebih ditekankan untuk mengoptimalkan kreativitasnya sehingga dapat disenangi anak-anak. Karena yang terpenting adalah anak mau belajar, dengan tetap mengacu kepada silabus dari pemerintah. Model dan metode pembelajaran yang digunakan juga lebih mengandalkan pada kemampuan dan pengetahuan guru dengan menyesuaikan keinginan dari peserta didik itu sendiri, karena pembelajaran diarahkan untuk membina kepribadian Islami anak yang disesuaikan dengan Visi dan Misi SMA Islam Terpadu Miftahul Khoir.
Adapun sarana dan prasarana pendidikan Islam di SMA Islam Terpadu Miftahul Khoir sudah cukup memenuhi standar ketentuan Depdiknas. Di antara sarana prasarana yang tersedia dikategorikan ke dalam dua jenis, yaitu sarana prasarana yang secara langsung digunakan dalam proses pembelajaran, terdiri dari ruang kelas, ruang laboratorium, ruang TU, dan ruang guru/perpustakaan, masjid, lapangan, Alqur'an, alat sholat, audio, proyektor, dan lingkungan sekitar sekolah, seperti lingkungan luar kelas masing-masing ataupun di area yang terdapat objek pembelajaran bidang studi tertentu. Sedangkan sarana prasarana SMA Islam Terpadu Miftahul Khoir yang tidak langsung digunakan untuk pembelajaran terdiri dari UKS, Toilet Ikhwan dan Toilet Akhwat, ruang BK, dan area parkir kendaraan. Yang menjadi unik terkait sarana prasarana langsung, di mana ruang guru, ruang TU, bahkan ruang kepala sekolah bisa dijadikan tempat pembelajaran, selain karena jumlah peserta didik yang relatif sedikit memang sekolah juga berusaha menciptakan lingkungan kekeluargaan, sehingga hubungan yang timbul tidak hanya sekedar antara guru Kekuatan lain dari manajemen sarana prasarana SMA Islam Terpadu Miftahul Khoir adalah lokasi sekolah yang sangat strategis, jauh dari kebisingan kendaraan, karena SMA Islam Terpadu Miftahul Khoir terletak di kawasan perumahan daerah Dago yang dekat dengan tebing. Sehingga mampu menciptakan lingkungan belajar yang kondusif dan menciptakan

TARBAWY: Indonesian Journal of Islamic Education - Vol. 4 No. 2 (2017) | 175 
iklim belajar Islami dengan didukung sarana prasarana yang menunjang pendidikan Islami SMA Islam Terpadu Mifahul Khoir.

Selanjutnya, manajemen pembiayaan pendidikan yang diperoleh melalui 3 sumber, yakni dari orang tua peserta didik, dari masyarakat, dan dari pemerintah yang dalam pengelolaannya sekolah memiliki warna manajemen tersendiri, sekolah tidak mengiblat kepada teori pembiayaan pendidikan tertentu. Adapun pengeluaran pendidikan di SMA Islam Terpadu Miftahul Khoir dialokasikan ke dalam 4 kategori, di antaranya untuk honor atau gaji tenaga pendidik dan tenaga kependidikan, untuk kegiatan sekolah, untuk kebutuhan rumah tangga seperti listrik, telpon, koran, termasuk di dalamnya ATK, dan untuk belanja barang (sarana prasarana pendidikan). Pengeluaran yang diprioritaskan misalnya, yakni untuk honor, karena biaya yang masuk maksimal $70 \%$ dari SPP peserta didik maka sistem pembagian honor dibagi menjadi dua waktu, yakni di awal bulan dan pertengahan bulan. Yang menjadi daya tarik dalam manajemen pembiayaan pendidikan Islam di SMA Islam Terpadu Miftahul Khoir adalah dengan tidak membocorkan urusan keuangan seperti SPP, DAP, dan Dana Kegiatan kepada para peserta. Jadi yang tahu hanyalah pihak sekolah dengan orang tua peserta didik saja, dengan alasan bahwa sekolah tidak ingin peserta didik terbebani dalam belajar dengan jumlah uang yang harus dibayar. Sekolah memiliki tujuan bahwa yang terpenting anak itu mau belajar, sesuai dengan Visi dan Misi yang ditetapkan. Inilah yang menjadi ciri khas dari manajemen pembiayaan pendidikan Islam di SMA Islam Terpadu Miftahul Khoir, yang dengan berbagai kekurangannya tetap mengutamakan kepuasan baik untuk para tenaga pendidik dan tenaga kependidikan maupun untuk peserta didiknya sendiri.

Dalam manajemen evaluasi pendidikan Islam dalam membina kepribadian Islami di SMA Islam Terpadu Miftahul Khoir bersifat integral. Evaluasi yang biasa dilaksanakan di SMA Islam Terpadu Miftahul Khoir terdiri dari evaluasi tulis, lisan, dan project juga praktek yang lebih diutamakan di sini. Sekolah lebih mengutamakan evaluasi dalam bentuk praktek karena memang praktek di sini menjadi pembiasaan sehari-hari bagi masing-masing peserta didik. Pembelajaran yang bertujuan untuk mengarahkan peserta didik sebagai insān kamil yang bertauhid menjadikan segala aktivitas sebagai bagian dari rangkaian evaluasi pembelajaran. Salah satunya melalui Pembiasaan Pagi dan Pembiasaan Sore, kegiatan sholat berjamaah, kegiatan-kegiatan dalam kebijakan program SMA Islam Terpadu Miftahul Khoir dijadikan sebagai bagian evaluasi pembelajaran. Sekolah tidak mengedepankan nilai akademik saja yang harus tinggi, melainkan sekolah berprinsip bahwa keberhasilan sebuah pendidikan atau pembelajaran dapat diukur dari perubahan yang dialami oleh masing-masing peserta didik. Sehingga dengan lebih menekankan pada kebiasaan sehari-hari yang 
dilakukan oleh peserta didik, baik itu dalam praktek ibadah sholat maupun dalam mata pelajaran lainnya, pendidikan akan menjadi sebuah pembiasaan yang mempribadi dalam diri peserta didik.

\section{REFERENSI}

Abdul Mujib; et.al. (2008). Ilmu Pendidikan Islam. Jakarta: Kencana.

Achmadi. (2009). Metodologi Penelitian. Jakarta: Bumi Aksara.

Afrinaldi. (2012). Konsep The Unity of Knowledge Ahmad Syafii Maarif dan Aktualisasinya Terhadap Praktek Pendidikan Islam di Indonesia. Yogyakarta: Pendidikan Agama Islam Fakultas Tarbiyah \& Keguruan UIN Sunan Kalijaga Yogyakarta.

Arifi, A. (2008). Anggaran Pendidikan dan Mutu Pendidikan. Jurnal Pendidikan Agama Islam Vol. 5 No. 1, 111-127.

Darmawan, B. (2014). Manajemen Sarana dan Prasarana dalam Meningkatkan Kualitas Pendidikan. Bowang-DarmawanManajemen-Saran-PrasaranaPendidikan.pdf, 94-102.

Djamarah, S. B. (2005). Guru dan Anak Didik dalam Integrasi Edukatif: Suatu Pendekatan Teoretis Psikologis. Jakarta: Rineka.

Fitriya, H. (2014, Februari 23). Sejarah Kurikulum di Indonesia 1945-2013. Dipetik Februari 09, 2017, dari Hidayatul Fitriya,s World: http://hidayatulfitriya.blogspot. co.id/2014/02/sejarah- kurikulum-di-indonesia-19452013.html

Karim, A. (2016). Pembaharuan Pendidikan Islam Multikulturalis. Jurnal Pendidikan Agama Islam Ta'lim vol. 14 no. 1, 19-36.

Khori, A. (Mei 2016). Manajemen Strategik dan Mutu Pendidikan Islam. Manageria: Jurnal Mutu Pendidikan Islam Volume I No. I, 75-99.

Kosim, M. (2008). Guru Dalam Perspektif Islam. Tadris Volume 3 Nomor I, 45.

Mahmudin, M. (2012, Agustus 15). Artikel Krisis Moral Pelajar. Retrieved Februari 12, 2017, from Makhshushotin: http://makhshushotin.blogspot. co.id/2012/08/artikel-krisismoral-pelajar.html

Moleong, L. J. (2014). Metode Penelitian Kualitatif. Bandung: PT Remaja Rosdakarya.

Muhaimin, \& al, e. (2012). Paradigma Pendidikan Islam. Bandung: PT Remaja Rosdakarya.

Nata, A. (2010). Ilmu Pendidikan Islam: Edisi Pertama. Jakarta: Kencana.

Purwakarta, H. (2014, Maret 26). Purwakarta Istimewa. Retrieved Januari 23, 2017, from Purwakarta Istimewa Web site: http://www.purwakartakab.go.i $\mathrm{d} /$ articles/tujuh-haripendidikan-istimewaimplementasi-pendidikanberkarakter-di-purwakarta

Qodar, N. (2015, Maret 15). Liputan 6. Retrieved Januari 24, 2017, from 
Liputan6.com:

https://m.liputan6.com/news/r

ead/2191106/survei-icrw-84-

anak-indonesia-alami-kekerasan-

di-sekolah

Rizal, A. S. (2010). Pendidikan Islami dalam Membina Kepribadian Islam. Jumal Pendidikan Agama Islam-Ta'lim Vol. 8 No. 1, 17-31.

Setyaningsih, K. (n.d.). Analisis Kepuasan Mahasiswa Terhadap Pelayanan Pendidikan di Prodi Manajemen Pendidikan Islam Fakultas Ilmu Tarbiyah dan Keguruan UIN Raden Fatah Palembang. Jurnal Idaroh, Vol. 1, No. 1, 33-44.

Sirozi, M., \& dkk. (2008). Arah Baru Studi Islam di Indonesia: Teori dan Metodologi. Jogjakarta: Ar-Ruzz Media.

Supriadi, D. (2006). Satuan Biaya Pendidikan Dasar dan Menengah. Bandung: PT Remaja Rosdakarya.

Syahidin. (2009). Menelusuri Metode Pendidikan dalam Alqur'an. Bandung: Alfabeta.

Tafsir, A. (2013). Ilmu Pendidikan Islami. Bandung: $\quad$ PT Remaja Rosdakarya.

Undang-Undang Sistem Pendidikan Nasional No. 20 Tabun 2003. (n.d.).

Waini Rasyidin; dkk. (2013). Landasan Pendidikan. Bandung: Sub Koordinator MKDP Landasan Pendidikan Jurusan Pedagogik FIP UPI. 